\title{
PENGARUH PENAMBAHAN EKSTRAK DAUN SALAM TERHADAP UMUR SIMPAN BAKSO
}

\author{
Tantri Yulianti, Dewi Cakrawati* \\ Program Studi Pendidikan Teknologi Agroindustri, FPTK UPI \\ Email: dewicakrawati@upi.edu
}

\begin{abstract}
Meatball, an Indonesian favorite food made from meat, seasoning and additives, is perishable due to high water content and nutrition. Therefore, in order to increase its shelf life, there was a need to add natural preservative that has the ability to prevent the growth of microorganism. The aim of the research was to determine the effect of addition of bay leaf extract on meatball characteristics. The research was conducted using bay leaf extract concentration as independent variable consisted four levels $(1,2$ and 3\%) and 0\% as control. Dependent variables consisted organoleptic characteristics, and number were measure each 2 days during 6 days storage. Result showed that addition of bay leaf extract extended meatball shelf life in room temperature for two days. After two days, meatball was deteriorated, as shown by high number of microorganisms, off-flavor, and soft texture.
\end{abstract}

Keywords: meatball, bay leaf extract, shelf life

\section{PENDAHULUAN}

Bakso daging adalah produk makanan berbentuk bulatan atau lain, yang diperoleh dari campuran daging ternak dan pati atau serealia (BSN, 1995). Bakso memiliki nutrisi yang baik dengan $\mathrm{pH}$ mendekati serta kadar air yang tinggi sehingga merupakan media pertumbuhan yang baik bagi mikroorganisme (Sugiharti, 2009). Hal ini menyebabkan umur simpan bakso pada suhu ruang sangat rendah yaitu 12 jam hingga 24 jam (Syamadi, 2002). Pengawetan bakso perlu dilakukan agar kualitas bakso dapat dipertahankan hingga kepada konsumen sehingga pengawetan memiliki dua fungsi yaitu mencegah kebusukan dan menjaga kualitas bahan pangan selama mungkin (Broto, 2003).

Salah satu cara untuk memper-tahankan kualitas bakso adalah dengan penambahan pengawet. Saat ini riset mengenai penggunaan pengawet alami terus dikembangkan seiring dengan banyaknya efek negatif dari penggunaan pengawet kimia (Ardiansyah, 2005). Mulyadi (2006) yang menunjukkan bahwa ekstrak daun salam dapat memperpanjang umur simpan bakso ikan patin yang disimpan pada suhu kamar selama 36 jam. Daun salam memiliki daya antibakteri terhadap beberapa bakteri patogen. Minyak esensial daun salam mengandung sitral, eugenol, tannin, dan flavonoida yang mempunyai aktivitas antioksidan yang sangat bermanfaat bagi kesehatan dan berperan penting untuk mempertahan-kan mutu produk pangan dari berbagai kerusakan seperti ketengikan, perubahan nilai gizi serta perubahan warna dan aroma makanan. Ekstrak etanol dari daun salam berfungsi sebagai antibakteri. Ekstrak etanol daun salam lebih efektif daripada daun salam yang diekstrak dengan pelarut air dalam menghambat pertumbuhan bakteri patogen (Kaveti et al., 2011).

Penambahan ekstrak daun salam pada produk makanan dapat memperpan-jang masa simpan karena memiliki daya penghambat aktivitas antibakteri. Penelitian Fitri (2007) mengenai penam-bahan ekstrak daun salam pada produk sosis sapi menunjukan bahwa konsentrasi $2 \%$ dapat memperpanjang umur simpan sosis selama 2 hari. Berdasarkan hal tersebut, peneliti bermaksud untuk melakukan penelitian mengenai pengaruh penambahan ekstrak daun salam terhadap umur simpan bakso. Penelitian ini bertujuan untuk mengetahui penambahan konsentrasi ekstrak 
daun salam untuk menghasilkan bakso yang diterima panelis serta mengetahui pengaruh penambahan ekstrak daun salam terhdap karakteristik bakso selama penyimpanan.

\section{METODE}

\section{Alat dan Bahan}

Alat yang digunakan yaitu peralatan membuat bakso, peralatan ekstraksi daun salam, serta peralatan analisis karakteristik bakso yang terdiri dari oven pengering, pengaduk, grinder, timbangan, gelas ukur, beaker, rotary vacum evaporator, tabung reaksi, erlenmeyer, penjepit cawan, hot plate, labu minyak, corong, termometer, inkubator, pinset, cotton buds, cawan petri, cakram kertas, penggaris serta perlengkapan uji organoleptik yang terdiri dari sendok dan piring.

Bahan yang akan digunakan dalam penelitian adalah ekstrak daun salam dan bahan penyusun bakso (daging ayam, tapioca, es, bawang putih, lada). Bahan yang digunakan untuk pembuatan ekstrak daun salam yaitu daun salam, etanol $95 \%$, aquadest. Bahan untuk uji bakteri adalah media Nutrient Agar (NA), desinfektan, antibiotika, biakan murni bakteri dalam medium cair.

\section{Tahapan penelitian}

1. Pembuatan ekstrak daun salam

Pembuatan ekstrak daun salam dengan metode maserasi mengacu pada penelitian Pratiwi (2007). Daun salam dikeringkan pada suhu $60^{\circ} \mathrm{C}$ kemudian dihancurkan dan direndam dalam etanol $80 \%$ sebanyak 2 ulangan. Ekstrak yang diperoleh kemudian dievaporasi.

2. Analisis aktivitas antibakteri ekstrak daun salam

Ekstrak daun salam dianalisis uji anti bakteri dengan metode zona bening dengan menggunakan Amoxicilin dan DMSO. Biakan dalam Nutrient Broth (NB) sebanyak 0,1 ml dimasukan ke dalam $15 \mathrm{ml}$ medium KNA yang sudah padat. Kemudian ekstrak daun salam dengan berbagai konsentrasi yaitu $30 \mathrm{mg}$ dan $500 \mathrm{mg}$ diambil menggunakan mikro pipet $0,01 \mathrm{ml}$ pada kertas cakram steril berdiameter $0,6 \mathrm{~cm}$ kemudian ditanam pada medium KNA padat dalam cawan petri. Setelah itu diinkubasi selama 24 jam pada suhu $37^{\circ} \mathrm{C}$. Selanjutnya diameter zona hambat diukur dan dibandingkan dengan kontrol.

3. Pembuatan bakso

Proses pembuatan bakso mengacu pada Tamal (2012). Diagram proses pembuatan bakso disajikan pada Gambar 1 .

\section{Kriteria Pengamatan}

\section{Pengamatan utama}

1. Analisis aktivitas antibakteri

Aktivitas anti bakteri dari ekstrak daun salam terhadap Staphylococcus aureus dilakukan dengan metode zona bening sebanyak dua kali ulangan.

2. Uji organoleptik

Pengujian terhadap penerimaan panelis dilakukan dengan uji organoleptik skala mutu hedonik untuk mengetahui tingkat kesukaan dari segi warna, aroma, tekstur dan rasa pada bakso. Panelis yang digunakan adalah panelis agak terlatih sebanyak 15 orang.

3. Uji Total Bakteri / Total Plate Count (TPC)

Penghitungan jumlah bakteri menggunakan metode cawan tuang (pour plate) Cappucino dan Sherman (1982). Sampel diencer-kan pada pengenceran $10^{-1}$ sampai $10^{-5}$. Masing-masing hasil pengenceran diambil dengan pipet sebanyak $1 \mathrm{ml}$ sampel dan dituangkan ke dalam cawan petri steril, kemudian diberi medium Plate Count Agar sebanyak $15 \mathrm{ml}$ pada suhu $37^{\circ} \mathrm{C}$ lalu dihomogenkan. Cawan petri yang berisi sampel diinkubasi pada inkubator pada suhu $37^{\circ} \mathrm{C}$ selama $24-$ 48 jam. Koloni bakteri yang tumbuh diamati dan dihitung. 


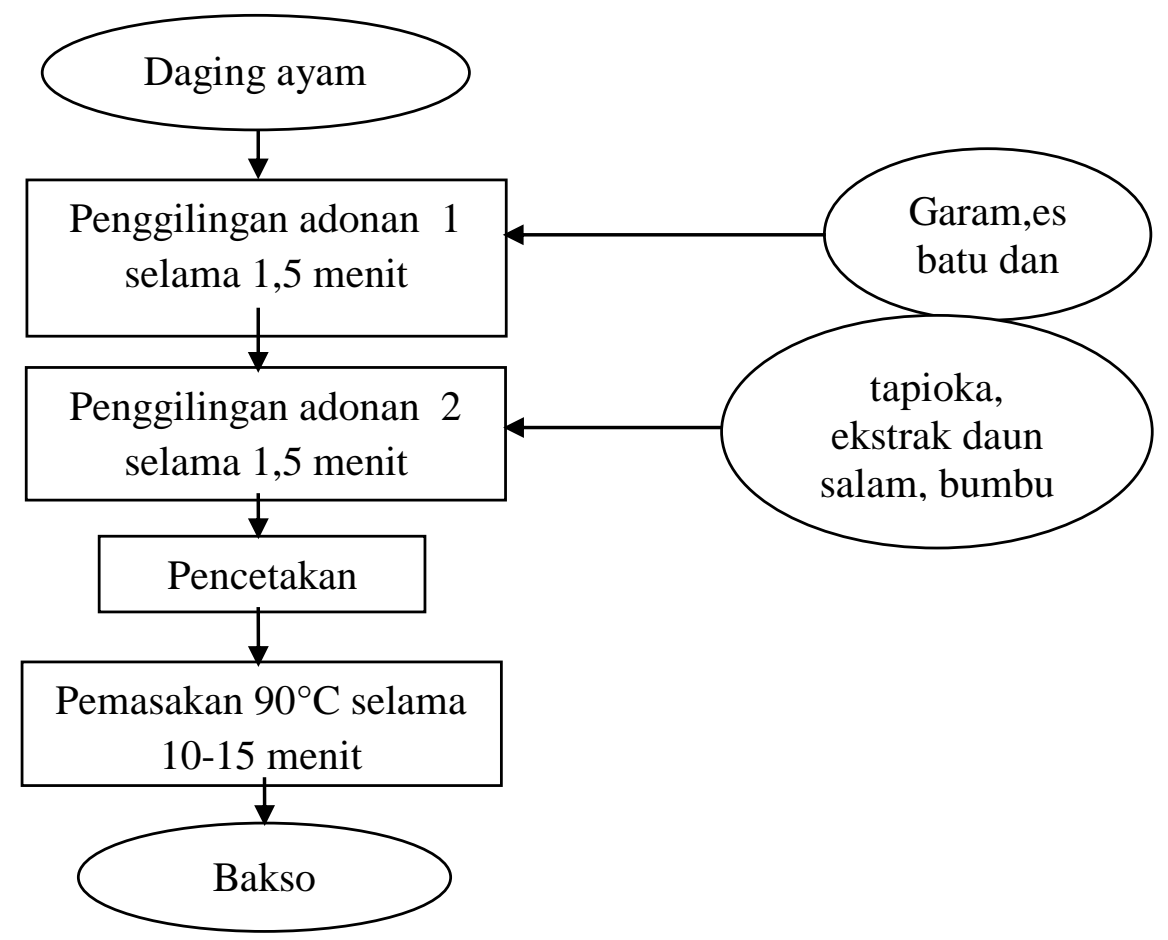

Gambar 1. Diagram Alir Pembuatan Bakso (Tamal, 2012)

\section{Metode Penelitian}

Bakso dengan penambahan ekstrak daun salam dengan perlakuan 1, 2 dan $3 \%$ diamati karakteristik organoleptik, total bakteri dan kadar air setiap dua hari selama penyimpanan 6 hari pada suhu ruang. Pengambilan data pada setiap variabel terikat dilakukan dengan 2 kali ulangan, sehingga data variabel terikat yang akan diolah menggunakan aplikasi minitab merupakan data rata-rata dari ulangan 1 dan ulangan 2 .

\section{HASIL DAN PEMBAHASAN}

\section{Analisis Anti Bakteri}

Hasil analisis aktivitas anti bakteri Staphylococcus aureus dari ekstrak daun salam menunjukkan zona bening sebesar ratarata 15,8 mm yang menunjukkan ekstrak daun salam. Namun penelitian yang dilakukan oleh Sumono dkk (2009) membuktikan senyawa antibakteri yang terkandung di dalam air rebusan daun salam mampu menghambat pertumbuhan bakteri seperti Streptococcus $s p$. Hasil analisis aktivitas anti bakteri ekstrak daun salam disajikan pada Gambar 2. Ekstrak daun salam mengandung 0,2\% minyak atsiri (sitral, eugenol), flavonoid (katekin dan rutin), tannin dan metil kavicol (methyl chavicol) yang dikenal juga sebagai estragole atau $p$ allylanisole

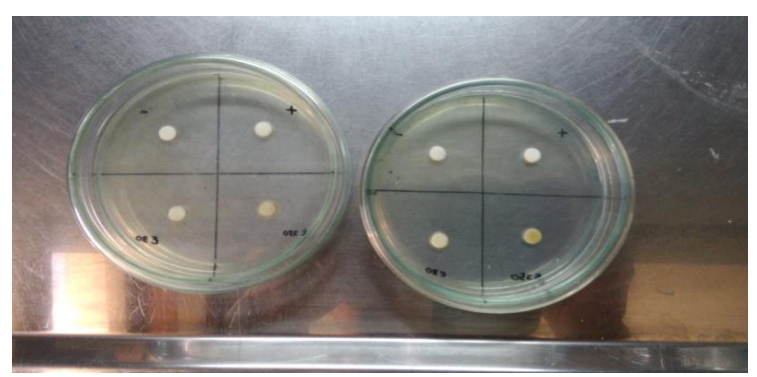

Gambar 2. Hasil Uji Antibakteri Ekstrak Daun Salam 


\section{Hasil Analisis Organoleptik Warna}

Menurut Winarno (2002), secara visual faktor warna tampil lebih dahulu dan kadangkadang sangat menentukan penerimaan suatu bahan pangan. Suatu bahan yang dinilai bergizi, enak, dan teksturnya sangat baik, tidak akan diterima apabila memiliki warna yang memberi kesan menyimpang dari warna yang seharusnya. Warna dapat mengalami perubahan saat pemasakan. Hal ini disebabkan oleh hilangnya sebagian pigmen yang diakibatkan pelepasan cairan sel saat pemasakan atau pengolahan, sehingga intensitas warna akan semakin menurun (Fellows, 1992). Hasil analisis warna pada bakso dengan perlakuan konsentrasi selama masa penyimpanan disajikan pada Gambar 3.

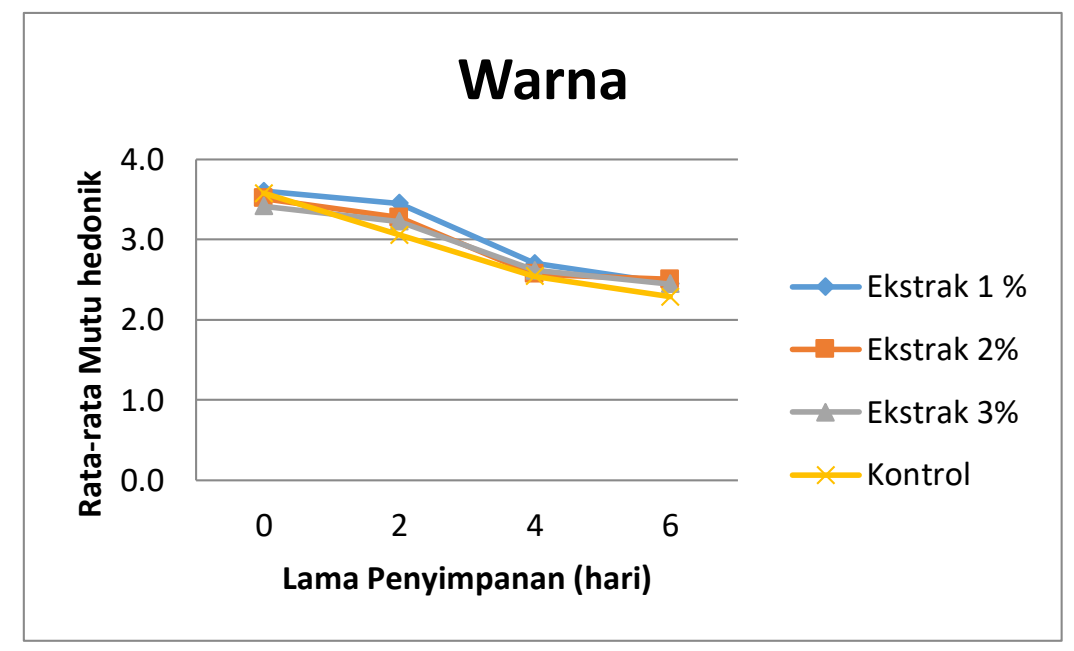

Gambar 3. Perubahan warna bakso selama penyimpanan

Gambar 3 menunjukkan penambahan ekstrak daun salam terhadap menurunkan nilai kesukaan warna bakso selama penyimpanan. Bakso dengan penambahan ekstrak daun salam memiliki warna putih keabuan yang berubah menjadi kuning seiring lama waktu penyimpanan.

\section{Rasa}

Rasa merupakan sifat organoleptik bakso yang memiliki peranan penting dalam penilaian konsumen. Rasa makanan dapat dikenali dan dibedakan oleh kuncup-kuncup pengecap yang terletak pada papila yaitu noda merah jingga pada lidah. Rasa bakso dapat ditentukan oleh komposisi persentase bumbu yang ditambahkan. Menurut DeMan (1997), flavor atau rasa merupakan rangsangan yang ditimbulkan oleh bahan yang dimakan, yang dirasakan oleh indra pengecap atau pembau, serta rangsangan lainnya seperti perabaan dan penerimaan derajat panas oleh mulut. Menurut Fennema (1992), parameter rasa berperan dalam menentukan tingkat penerimaan suatu bahan pangan oleh konsumen. Hasil analisis rasa pada bakso dengan penambahan esktrak daun salam selama masa penyimpanan disajikan pada Gambar 4. 


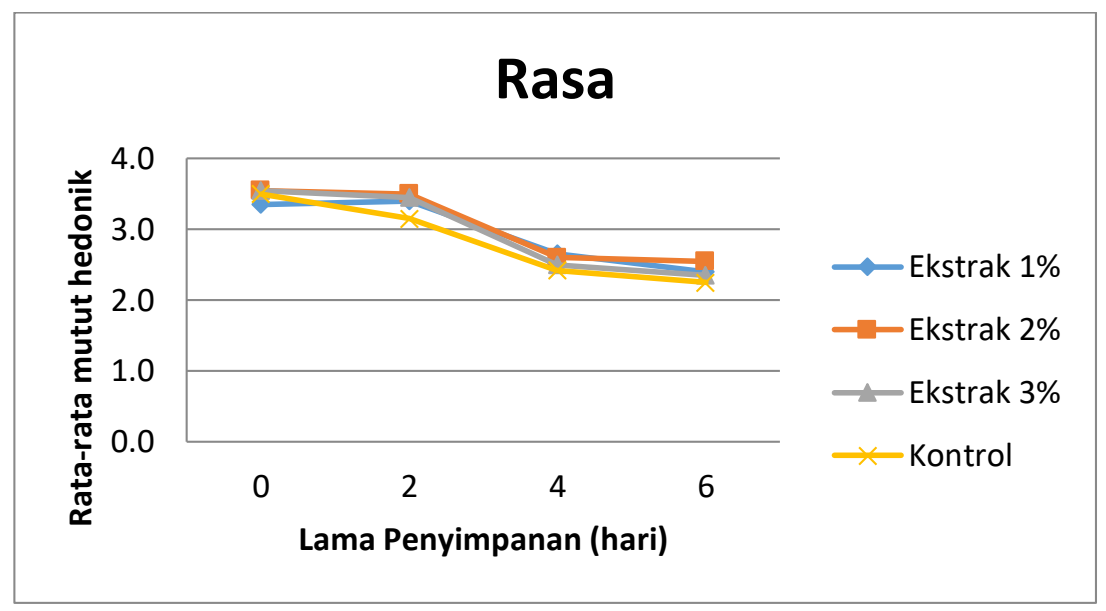

Gambar 4. Perubahan rasa bakso selama penyimpanan

Gambar 4 menunjukkan bahwa penyimpanan bakso selama 6 hari di suhu ruang menyebabkan terjadinya penurunan nilai kesukaan terhadap rasa bakso. Hal-hal yang mempengaruhi kualitas rasa adalah senyawa kimia, suhu, konsentrasi, dan interaksi dengan komponen rasa yang lain. Air juga dapat melarutkan berbagai macam bahan seperti garam, vitamin yang larut dalam air, mineral, dan senyawa-senyawa cita rasa (Winarno, 1992).

\section{Aroma}

Aroma pada bakso sebagian besar berasal dari bumbu-bumbu yang ditambahkan pada adonan. Semakin banyak bumbu-bumbu yang ditambahkan maka aroma yang dihasilkan semakin kuat. Penggunaan tepung yang terlalu banyak akan mengurangi aroma daging pada bakso (Purnomo, 1990). Hasil anali-sis aroma bakso dengan penambahan ekstrak daun salam selama masa penyimpanan disajikan pada Gambar 5.

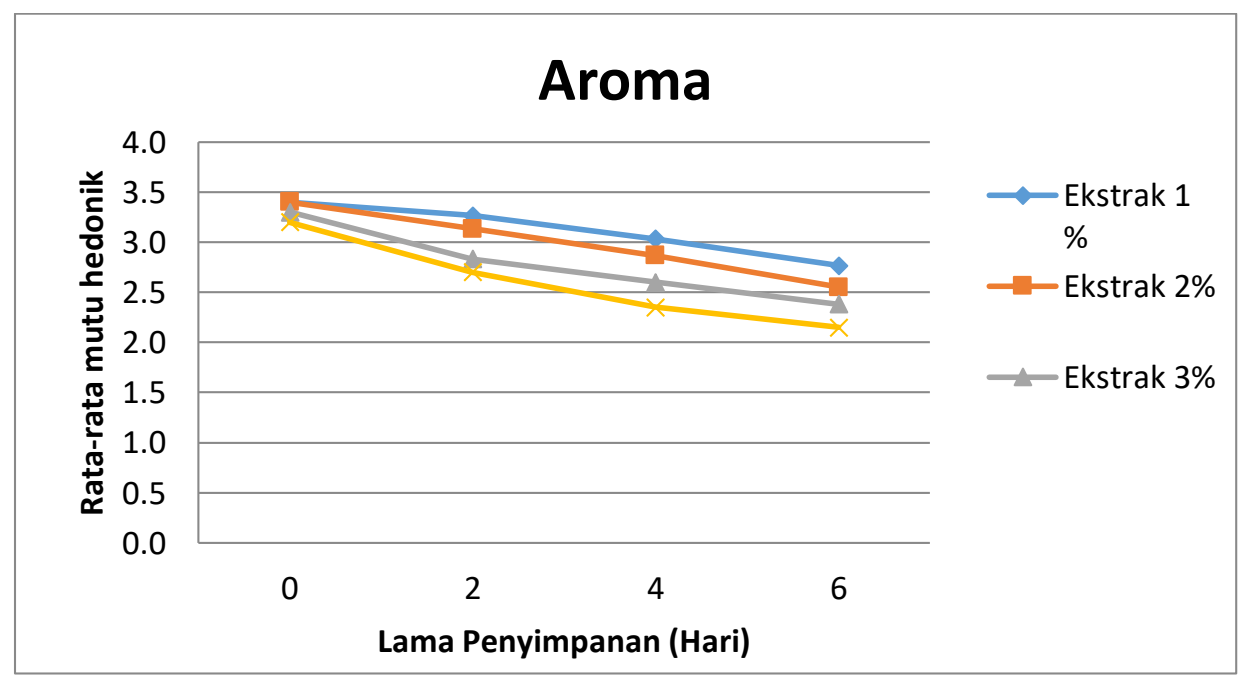

Gambar 5. Perubahan aroma bakso selama penyimpanan

Gambar 5 menunjukkan penurunan nilai aroma bakso selama penyimpanan 6 hari Semakin tinggi konsentrasi ekstrak daun salam yang ditambahkan, semakin rendah nilai aroma bakso. Hal ini sejalan dengan penelitian yang dilakukan oleh Hadittama 
(2009) yang menyatakan semakin tinggi konsentrasi ekstrak bawang putih yang ditambahkan menghasilkan penurunan nilai aroma pada bakso sapi. Aroma daun salam membuat aroma bakso menjadi tertutupi. Aroma tersebut berkaitan dengan kandungan minyak atsiri yang terkandung dalam ekstrak daun salam dan sulit untuk dihilangkan karena mengandung senyawa fenol yang memiliki cincin aromatik (Apriandi, 2009).

Bakso mulai mengalami kerusakan pada hari keempat sehingga aroma bakso menyimpang. Adanya mikroorganisme menyebabkan timbulnya aroma menyim-pang akibat adanya aktivitas enzim lipase dan protease (Jay, 2005).

\section{Tekstur}

Menurut Fellows (1992), tekstur makanan ditentukan oleh kandungan air, lemak, protein, dan karbohidrat. Perubahan tekstur dapat disebabkan oleh hilangnya air atau lemak, pembentukan emulsi, hidrolisis karbohidrat dan koagulasi protein. Penelitian Andayani (1999) menunjukkan konsumen lebih menyukai bakso yang kompak dengan tekstur yang halus. Hasil analisis organoleptik pada tekstur bakso dengan penambahan ekstrak daun salam disajikan pada Gambar 6.

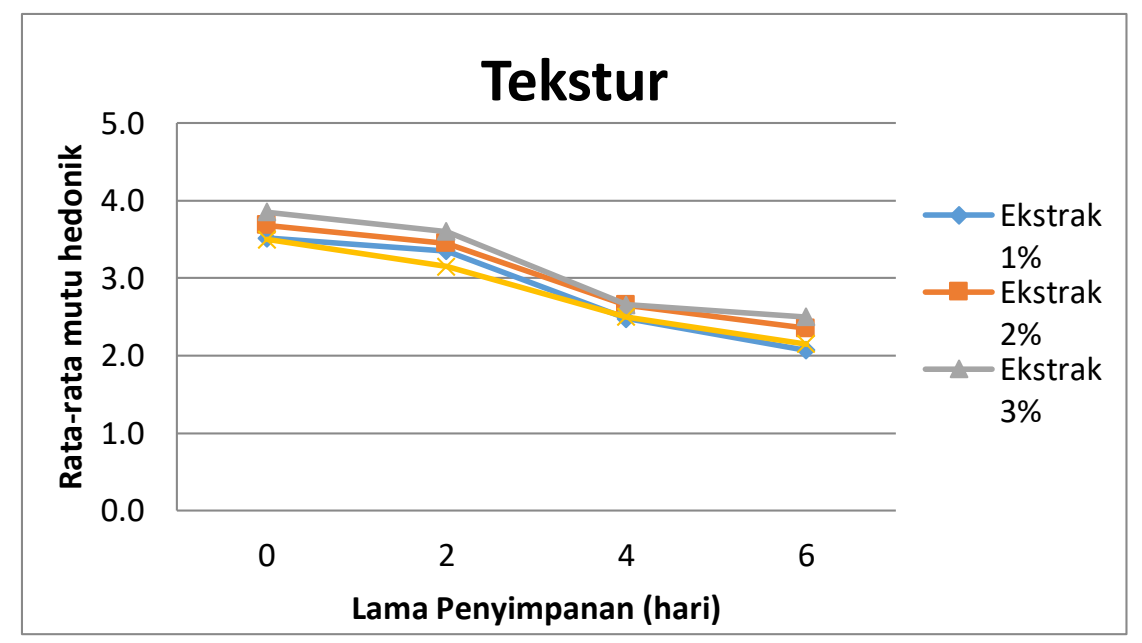

Gambar 6. Perubahan Tekstur Bakso Selama Penyimpanan

Gambar 6 menunjukkan nilai tekstur bakso menurun selama penyimpanan 6 hari. Hal ini menunjukan adanya kerusa-kan pada bakso yang ditunjukkan oleh adanya lendir karena kekompakan bakso yang semakin berkurang (Prastawa dkk, 1980). Selain itu, penurunan tingkat kekerasan bakso disebabkan tingginya angka total mikroba yang menyebabkan pelunakan bakso karena komponen protein dan lainnya didegradasi oleh bakteri sebagai sumber nutrisi. Hasil yang diperoleh pada penelitian ini berbeda dengan penelitian sejenis yang dilakukan oleh Hadittama (2009), yaitu bakso yang dicelup dan direbus dengan larutan pengawet ekstrak bawang putih pada konsentrasi 10,15 , dan $20 \%$ terus mengalami peningkatan tingkat kekerasan selama penyimpanan. Berdasarkan variasi ekstrak daun salam menunjukan tidak ada pengaruh terhadap bakso.

\section{Analisis Jumlah Mikroorganisme}

Total mikroba perlu diketahui untuk memastikan suatu bahan pangan layak untuk dikonsumsi. Pertumbuhan mikroba dalam bahan pangan erat hubungannya dengan jumlah kandungan air. Kebutuhan mikroba akan air biasanya dinyatakan dalam aktivitas air (Aw). Produk bakso memiliki aw yang tinggi sehingga cocok sebagai media pertumbuhan mikro-organisme. Secara fisik, bakso sudah berlendir, muncul bau menyengat dan terjadi perubahan warna. Sesuai dengan hal tersebut, bakso terkontaminasi dengan jamur. Menurut SNI 01-0366-2000 juga dinyatakan bahwa mikroba yang melebihi batasan normal dapat disebabkan oleh daging 
yang digunakan memiliki jumlah mikroba diambang batasan normal dan terjadi kontaminasi dari alat-alat yang digunakan.
Nilai Total mikroba bakso selama 6 hari disajikan pada Gambar 7.

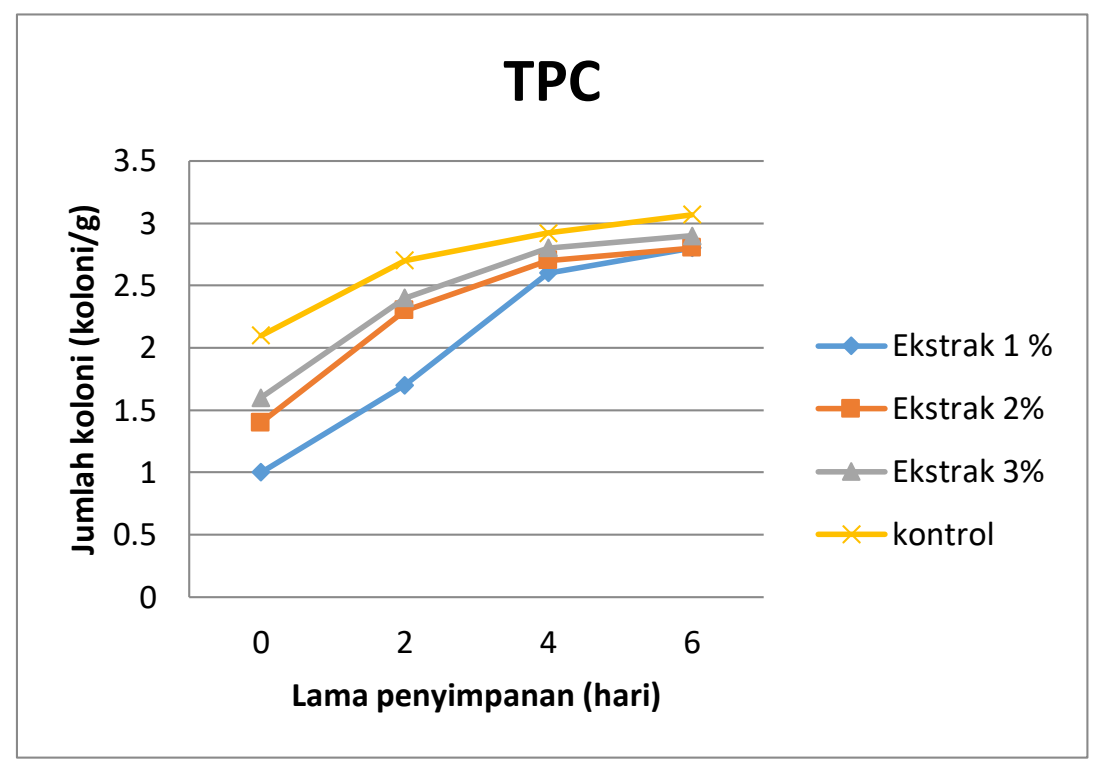

Gambar 7. Grafik rata-rata Nilai TPC Bakso pada 6 hari Penyimpanan

Hasil penelitian menunjukan bahwa penyimpanan bakso selama 6 hari pada suhu ruang menyebabkan terjadinya kenaikan jumlah mikroba pada bakso. Setelah disimpan dua hari hari, total mikroba bakso yang ditambah ekstrak daun salam $1 \%$ dan $2 \%$ telah melewati batas SNI yaitu $1 \times 10^{5}$ koloni/g. Penelitian Wicaksono (2007) dihasilkan bahwa pada hari ke-1, analisis Total Plate Count bakso yang ditambah sulfit dan tanin, campuran pengawet serta chitosan antara 5-6 $\log \mathrm{cfu} / \mathrm{gr}$ atau telah melebihi ketetapan standar SNI, tetapi pada bakso tersebut belum ditemui adanya tanda-tanda kerusakan mikrobiologis. Pada hari ke-2, bakso yang ditambah sulfit dan tanin serta bakso yang dicoating chitosan total mikrobanya sudah mencapai 6,55 dan 5,77 log cfu/g.

Peningkatan jumlah mikroba disebabkan oleh beberapa faktor yaitu lama penyimpanan, dan kadar air. Pertumbuhan mikroba terjadi dalam waktu singkat pada kondisi tersedianya kandungan nutrisi (air, protein, lemak, vitamin dan mineral) sebagai sumber energi untuk berkembang biak (Jay, 2005).

\section{KESIMPULAN}

Kesimpulan dari penelitian ini adalah penggunaan ekstrak daun salam dapat memperpanjang masa simpan bakso pada suhu ruang $\left(27{ }^{\circ} \mathrm{C}\right)$ sampai hari ke-2. Hasil analisis organoleptik, TPC dan kadar air menunjukan bahwa penambahan konsentrasi ekstrak daun salam 1 dan $2 \%$ merupakan konsentrasi yang optimal untuk memperpanjang masa simpan bakso pada suhu ruang $\left(27^{\circ} \mathrm{C}\right)$ sampai hari ke- 2 .

\section{DAFTAR PUSTAKA}

Affandy. 2005. Pengaruh Kondisi Bahan dan Lama Ekstraksi Daun salamTerhadap Sifat Fisiko-kimia dan Aktivitas Antibakteri Esktrak Oleoresin Daun Salam. Skripsi. Jurusan Teknologi Hasil Pertanian. Universitas Brawijaya. Malang.

Andayani, R. 1999. Standardisasi mutu bakso sapi berdasarkan kesukaan konsumen. (Studi kasus bakso di Wilayah DKI Jakarta). Skripsi. Fakultas Teknologi Pertanian, Institut Pertanian Bogor, Bogor.

Apriandi, A. 2011. Aktivitas Antioksidan dan Komponen Bioaktif Keong Ipong-Ipong (Fasciolaria salmo). Skripsi. Fakultas Perikanan dan Ilmu Kelautan, Institut Petanian Bogor. Bogor. 
Broto, W., 2003. Teknologi Penanganan Pascapanen Buah untuk Pasar. Agromedia Pustaka, Jakarta.

Badan Standarisasi Nasional. 1995. Bakso Daging. SNI 01-3818-1995. Dewan Standarisasi Nasional, Jakarta

deMan. J. M. 1997. Kimia Makanan. Terjemahan: K. Panduwinata. ITB Press, Bandung.

Fellow, P.J. 1992. Food Processing Technology. New York:CRC Press

Fennema, O.R. Editor. 1996. Food Chemistry, 3rd ed. Marcel Dekker. New York

Fitri, A. 2007. Pengaruh Ekstrak Daun Salam Terhadap Karakteristik Fisik dan Umur Simpan Sosis. Skripsi. Universitas Pasundan, Bandung

Hadittama, N. 2009. Studi Penggunaan Ekstrak Bawang Putih (Allium sativum LINN) pada Pengawetan Bakso Dengan Asam Asetat. Skripsi, Fakultas Teknologi Pertanian. Institut Pertanian Bogor, Bogor.

Harismah, K Dan Chusniatun. 2017. Pemanfaatan Daun Salam (Eugenia Polyantha) Sebagai Obat Herbal Dan Rempah Penyedap Makanan. Journals.Ums.Ac.Id/Index.Php/Warta/A rticle/Download/2742/2167

Jay, J.M. 2005. Modern Food Microbiology. Seventh edition. Springer Science and Business media.

Kaveti, B., L. Tan, Sarnnia, T.S. Kuan dan M. Baig. 2011. Antibacterial Activity of Piper betle leaves. Int. J. Pharm. Teaching \& Practise, 2 (3): 129- 132.

Mulyadi, S. 2010. Pengaruh Penambahan Ekstrak Daun Salam Terhadap Mutu dan Umur Simpan Bakso Ikan Patin. Skipsi. Fakultas Teknologi Pangan. Universitas Brawijaya, Malang.

Mulyani Y, Bachtiar E, A Untung. 1999. Peranan senyawa metabolit sekunder tumbuhan mangrove terhadap infeksi bakteri Aeromonas hydrophila pada ikan mas (Cyprinus carpio L.). Jurnal Akuatika. 2013, 4 (1) 1-9
Prastawa, I.M.A.D, Wiwik S.R. dan Raditya Y. 2009. Isolasi Dan Uji Antiradikal Bebas Minyak Atsiri pada Daun Salam (Piper betle Linn) Secara Spektroskopi Ultra Violet-Tampak. Jurnal Kimia 3 (1):7-13. ISSN: 1907-9850.

Pratiwi, E. Hadiwiyoto, IS. 2007. Optimasi produksi Minyak daun salam (Syzygium polyanthum) dan identifikasi senyawa volatilnya. Dissertasi. Universitas Gajah Mada.

Purnomo, H. 1990. Kajian mutu bakso daging, bakso urat, dan bakso aci di Bogor. Skripsi. Institut Pertanian Bogor. Bogor.

Sugiharti, S. 2009. Pengaruh Perebusan dalam Pengawet Asam Organik Terhadap Mutu Sensori dan Umur Simpan Bakso. Skripsi. Fakultas Teknologi Pertanian. Institut Pertanian Bogor. Bogor.

Sumono A, Wulan A. 2009. Kemampuan air rebus daun salam (Eugenia polyantha w) dalam menurunkan jumlah koloni bakteri streptococcus sp. Majalah Farmasi Indonesia, 20 (3), 112-7.

Syamadi, R.K. 2002. Aplikasi Penggunaan H2O2 dan Radiasi dalam Pengawetan Bakso Sapi pada Penyimpanan Suhu Kamar. Skripsi. Fakultas Teknologi Pertanian. Institut Pertanian Bogor, Bogor.

Tamal, MA, E. Abustam, L. Rahim. 2012. Kajian kualitas bakso sapi hasil rendaman dengan pengawet dari ekstrak bawang putih (Allium sativum L.) secara fisikokimia dan mikrobiologi. Thesis. Universitas Hasanuddin.

Wicaksono, D.A. 2007. Pengaruh Metode Aplikasi Kitosan, Tanin, Natrium Metabisulfit dan Mix Pengawet Terhadap Umur Simpan Bakso Daging Sapi pada Suhu Ruang. Skripsi. Fakultas Teknologi Pertanian. Institut Pertanian Bogor. Bogor.

Winarno, F.G., 2002. Kimia Pangan dan Gizi. PT. Gramedia Pustaka Utama, Jakarta. 